Original Contribution

\title{
EFFECT OF FEED SUPPLEMENTATION WITH GARLIC POWER ON MEAT PRODUCTIVITY AND MEAT QUALITY TRAITS OF CLASSIC ROSS 308 MALE HYBRID CHICKENS
}

\author{
H. Lukanov ${ }^{1 *}$, A. Genchev ${ }^{1}$, S. Ribarski ${ }^{2}$ \\ ${ }^{1}$ Department of Animal Science - Monogastric and Other Animals, Faculty of Agriculture, \\ Trakia University, Stara Zagora, Bulgaria \\ ${ }^{2}$ Department of Animal Morphology, Physiology and Nutrition, Faculty of Agriculture, \\ Trakia University, Stara Zagora, Bulgaria
}

\begin{abstract}
Fresh garlic contains natural phytobiotics, whereas garlic powder - several biologically active substances with prebiotic activity. The purpose of the study was to evaluate the effect of feed supplementation with garlic powder on growth performance, carcass yield and meat quality in broiler chickens. The experiment was conducted with 120 male broiler chickens divided into 4 groups: group I - control; groups II, III and IV - supplemented with $0.2 \% ; 0.4 \%$ and $0.8 \%$ garlic powder, respectively. The experiment lasted up to the $56^{\text {th }}$ day of age. Growth performance of birds was determined, and at 56 days of age - slaughter analysis was performed for evaluation of slaughter traits, $\mathrm{pH}$, water holding capacity (WHC) and colour $\left(\mathrm{L}^{*}, \mathrm{a}^{*}, \mathrm{~b}^{*}\right)$ of Musculus pectoralis superficialis, Musculus pectoralis profundus and Musculus femorotibialis medialis. The results demonstrated a steady tendency towards increase in live body weight throughout the fattening period proportionally to the level of dietary garlic powder supplementation. After feed supplementation with increasing doses of garlic powder, feed conversion ratio $(\mathrm{kg} / \mathrm{kg})$ maintained a stable positive tendency up to the $7^{\text {th }}$ week of age. Garlic powder supplementation did not influence the proportion of edible offal and meat cuts, except for abdominal fat percentage. Added to poultry feed at levels up to $0.8 \%$, garlic powder had no adverse effect on chicken meat quality, but an increased tenderness of Musculus pectoralis superficialis was established.
\end{abstract}

Key words: prebiotic, FOS, growth traits, slaughter traits, meat quality

\section{INTRODUCTION}

During the last decades, phytobiotics, probiotics and prebiotics have witnessed an increased application in modern animal husbandry consequently to problems emerging from the use of nutritional antibiotics and general antibiotic resistance (1).

The use of probiotics in poultry farming is associated with increased resistance to bacterial and protozoan diseases, improved feed conversion and better growth performance (2). On the other hand, the gastrointestinal tract

\footnotetext{
*Correspondence to: Hristo Lukanov, PhD student at Department of "Animal Science - monogastric and other animals", Faculty of Agriculture, Trakia University,6000 Stara Zagora, Bulgaria, e-mail: dr_lukanov@abv.bg, telephone: +359/898419751.
}

(GIT) of birds is colonised by both "useful" and "harmful" microorganisms (3), and the share of the former could be positively altered through appropriate nutrition and maintenance of favourable conditions for growth and replication.

Prebiotics are non-digestible nutritional ingredients which stimulate the growth and activity of useful intestinal microflora. Thus, they exert a positive effect on the entire body as well (4). The supplementation of poultry feed with prebiotics contributes to maintaining the intestinal health, improves production traits, increases the conversion of nutrients, decreases the production costs and helps maintaining a proper environment (5). Most commonly used prebiotics are from the group of oligosaccharides: fructooligosaccharides (FOS), inulin, oligofructose, isomaltooligosaccharides 
etc. Garlic, chicory, onion, artichoke, asparagus, bananas, wheat, tomatoes etc. are rich in inulin and FOS (6-8).

Garlic (Allium sativum) is extensively used worldwide as a spice, and also in folk and traditional medicine for control of some infectious and non-infectious diseases, including blood plasma and liver cholesterol reduction (910). Garlic powder contains fructooligosaccharides (FOS) with prebiotic activity (11). Moreover, garlic powder contains various levels of alliin (12), has a rich vitamin content (vitamin $\mathrm{C}$, thiamine, riboflavin and niacin), selenium and potassium (13). The addition of garlic powder to the feed of chickens had a beneficial effect on their growth and meat performance (14-16). Gerzilov et al., (17) utilised garlic powder in a multicomponent phytosupplement to stimulate the production in chickens from the AN line.

Numerous researchers have assessed the effects of different dietary levels garlic powder on growth characteristics, feed consumption and slaughter traits in broiler chickens. Gbenda et al. (18) demonstrated that feed supplementation with $0.5 \%$ and $0.05 \%$ garlic powder improved growth performance and reduced the abdominal fat percentage. In an experiment evaluating feed supplementation with $0.05 \%$ and $0.1 \%$ garlic powder, Fayed et al. (19) reported better growth performance and carcass yield in supplemented groups. The beneficial effect of garlic powder on growth performance of broilers fed a diet with $0.1 \%$ garlic powder vs non-supplemented birds was also reported by Mansoub (20). Kim et al. (21) suggested that the addition of garlic byproducts to poultry feed would improve the lipid profile and the quality of meat due to the improved texture and flavour. Choi et al. (22) reported higher values of meat colour coordinates $\mathrm{a}^{*}$ (redness) and $\mathrm{b}^{*}$ (yellowness) with decreased $\mathrm{L}^{*}$ (lightness) of thigh muscles proportionally to the amount of dietary garlic powder (from $1 \%$ to 5\%). Dzinic et al., (23) established that the addition of $2 \%$ garlic powder to the feed of broiler chickens increased statistically significantly breast meat yield. Abdullah et al. (24) found out a lower feed consumption in broiler chickens fed rations supplemented with $0.5 \%$ and $1 \%$ garlic powder.

\section{PURPOSE}

The purpose of the study was to evaluate the meat productivity and meat quality traits of classic male hybrid broiler chickens receiving different dietary levels of garlic powder with their feed.

\section{MATERIALS AND METHODS}

The experiment was carried out in the Experimental base of the Poultry Science Unit, Faculty of Agriculture, Trakia University - Stara Zagora in the autumn of 2013. The subjects of the study were 120 day-old male Ross 308 broiler chickens allotted to 4 equal groups with identical body weight. Each group consisted of 3 subgroups with 10 broiler chickens originating from a certified hatchery:

- First group - control;

- Second group - fed ration supplemented with $0.2 \%$ garlic powder;

- Third group - fed ration supplemented with $0.4 \%$ garlic powder;

- Fourth group - fed ration supplemented with $0.8 \%$ garlic powder.

The nutrition facts of the used garlic powder were as followed: ME: $3310 \mathrm{kcal} / \mathrm{kg}$; crude protein: $16.55 \%$; crude fat: $0.73 \%$; crude fibre: 9.0\% lysine: $0.77 \%$; methionine: $0.11 \%$; threonine: $0.37 \%$; tryptophan: $0.12 \%$; Ca: 0.08\%; P: $0.41 \%$ (13).

The experiment was compliant with all animal hygiene requirements and poultry welfare issues. Subgroups were housed in 12 separate cages. Throughout the experiment, ambient temperature and light day duration were controlled as per the requirements of meat hybrid manufacturer (25). The trial was conducted until the $56^{\text {th }}$ day of age of broilers.

Phase-feeding was used and all groups received feed with equal energy, protein, amino acid and mineral content:

- $\quad$ Starter (0-10 days of age): $12.65 \mathrm{MJ} / \mathrm{kg}$ ME, $23 \%$ crude protein, $1.43 \%$ lysine, $0.51 \%$ methionine, $0.94 \%$ threonine; $1.05 \% \mathrm{Ca}, 0.5 \%$ available $\mathrm{P} ;<4.00$ crude fibre;

- $\quad$ Grower (11-24 days of age): $13.20 \mathrm{MJ} / \mathrm{kg}$ ME, $21 \%$ crude protein, $1.24 \%$ lysine, $0.45 \%$ methionine, $0.83 \%$ threonine, $0.9 \% \mathrm{Ca}, 0.45 \%$ available. $\mathrm{P},<4.00$ crude fibre;

- $\quad$ Finisher 1 (25-42 days of age): 13.40 $\mathrm{MJ} / \mathrm{kg} \mathrm{ME}, 19 \%$ crude protein, $1.06 \%$ lysine, $0.40 \%$ methionine, $0.85 \% \mathrm{Ca}, 0.42 \%$ available $\mathrm{P}$; $<4.00$ crude fibre;

- $\quad$ Finisher 2 (43-56 days of age): 13.50 $\mathrm{MJ} / \mathrm{kg} \mathrm{ME}, 17 \%$ crude protein, $1.00 \%$ lysine, $0.35 \%$ methionine, $0.8 \% \mathrm{Ca}, 0.40 \%$ available $\mathrm{P}$; $<4.00$ crude fibre.

The following growth performance traits were evaluated: 
- Live body weight, g;

- Weight gain, g;

- Daily Feed intake, g;

- Total feed intake during the experimental period, $g$ (0-56 days of age);

- Feed conversion ratio (FCR).

At 56 days of age after 6-hour fasting, 3 birds from each group with weight corresponding to the group average were slaughtered. To avoid the influence of heat processing on colour traits of breast muscle, the initial processing of carcasses was done without scalding. With respect to a more correct slaughter analysis, carcasses were identified by individual numbers and then weighed with precision of $0.01 \mathrm{~g}$ with ACBplus-300 balance. The carcasses were cut, and cut weights measured with a precision of $0.01 \mathrm{~g}$. Carcass yield and relative proportions of cuts with bone and deboned breast and thigh meat were calculated.

Time course of $\mathrm{pH}$ and colour characteristics of Musculus pectoralis superficialis, Musculus pectoralis profundus and Musculus femorotibialis medialis was studied on post slaughter min 30 and hours 4 and 24 . Determination of $\mathrm{pH}$ was done with portable NESTO $\mathrm{pH}$ meter equipped with glass electrode, preliminary calibrate in standard solutions with pH 4.0 and pH 7.0. Muscle colour was expressed in the CIELAB colour system (26) using a Lovibond SP60 spectrophotometer (X-Rite Incorporated), preliminary calibrated with white and black standards.

The water holding capacity of meat and its tenderness were determined on post slaughter hour 24. Water holding capacity of muscles was evaluated by compression of muscle tissue sample on a filter paper (red strip 388), placed between two glass slides and pressed with a $5-\mathrm{kg}$ weight for $5 \mathrm{~min}$ (27). Water holding capacity of muscles was calculated by the equation:

$\mathrm{WHC}=\left(1-\frac{A-B}{A}\right) \times 100$.

where: WHC- water holding capacity of muscles, $\%$;

A - mass of muscle sample prior to pressing, $\mathrm{g}$;

$\mathrm{B}$ - mass of muscle sample after pressing, $\mathrm{g}$.

The tenderness of Musculus pectoralis superficialis was determined with penetrometer RA-1, equipped with a penetration tip. The device measured the depth of tip penetration in a muscle sample under the pressure exerted by the needle, here $103.3 \mathrm{~g}$. Tenderness values are expressed as degrees of penetration $\left({ }^{\circ} \mathrm{P}\right)$, where 1 ${ }^{\circ} \mathrm{P}=0.1 \mathrm{~mm}$.

Results were processed by means of routine statistical analyses in MS Excel 2010 environment.

\section{RESULTS AND DISCUSSION}

The data presented on Figure 1 demonstrate that average body weight of broilers was very close to that indicated in the technological documentation of the strain Ross 308. The weight development of experimental boilers was better compared to that of controls, and the difference was higher from 14- until 28 days of age. There is a positive effect from garlic powder supplement with highest body weight in broilers from group IV. After the $28^{\text {th }}$ day, the differences decreases and at 56 days of age they varied between 0.2 and $1.6 \%$. It was established that after 35 days of age, the body weight of broilers was influenced by the dietary level of garlic powder. A similar trend was also reported by Elagib et al. (16), Gbenda et al. (18), Fayed et al. (19), Mansoub (20). In agreement with our results, Raeesi et al. (14), found out that feed supplementation with garlic powder during the finisher period had a positive effect on the growth performance of birds. On the opposite, Choi et al. (22) и Abdullah et al. (24) did not establish any beneficial influence on the growth of broiler chickens.

As seen from Figure 2, feed intake by broilers was lower between the $6^{\text {th }}$ and the $16^{\text {th }}$ day of life compared to the technological norm for Ross 308. By the middle of the experimental period, chickens from all groups tended to consume more feed. Despite the between-group differences during the age periods, the feed intake throughout the 56 experimental days was similar to specified norms. In this study, no correlation was established between feed intake and dietary garlic powder concentrations $<0.8 \%$. Unlike our data, Abdullah et al. (24) reported lower feed intake in groups receiving feed supplemented with $0.5 \%$ and $1 \%$ garlic powder.

Data from Table 1 revealed a direct relationship between body weight of chickens and the dietary garlic powder level. The correlation was stable between 35 and 56 days of age, with statistically significant differences at $35(\mathrm{P}<0.001)$ and 49 $(\mathrm{P}<0.01)$ days of age. In general, all groups exhibited lower body weights than values specified by hybrid manufacturer. This could be attributed to the environment, whose tests have 
shown to be nearly the same as the ideal

conditions for Ross 308 chickens.

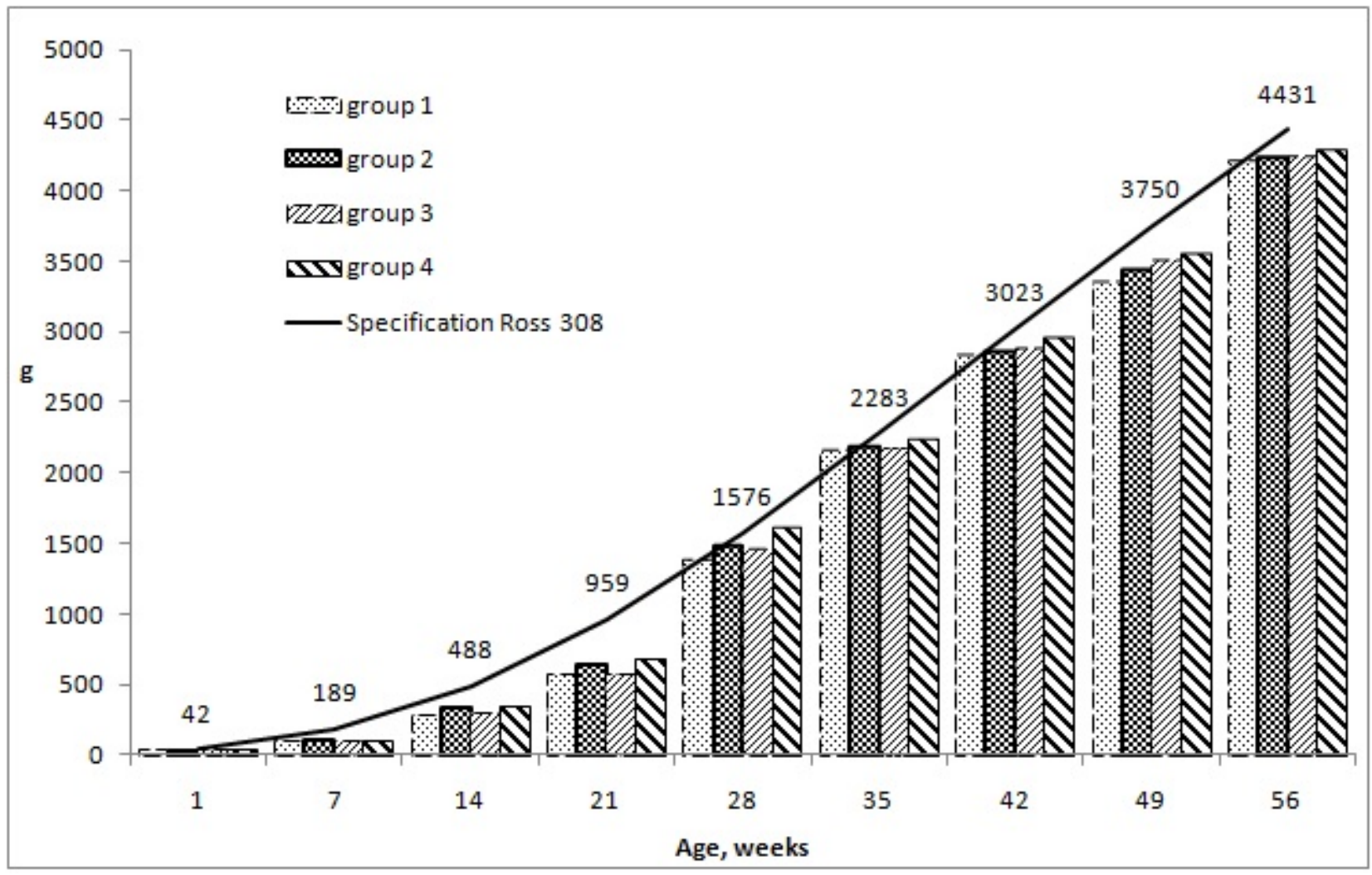

Figure 1. Average body weight, g.

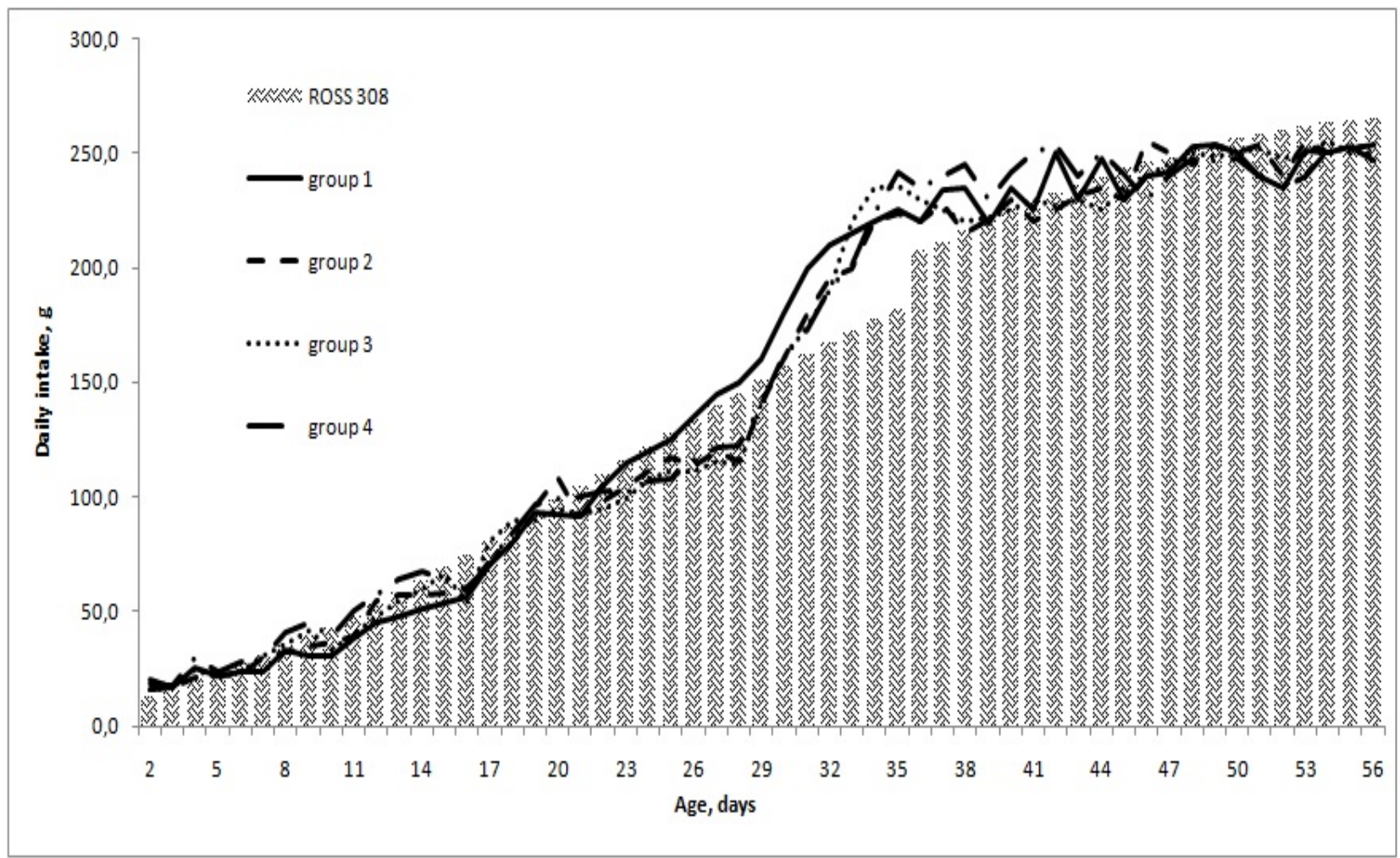

Figure 2. Daily feed intake, g.

Trakia Journal of Sciences, Vol. 13, № 1, 2015 
Table 1. Growth performance

\begin{tabular}{|c|c|c|c|c|c|c|c|c|c|}
\hline \multirow[b]{2}{*}{ Indications } & \multirow[b]{2}{*}{$\begin{array}{l}\text { Age, } \\
\text { days }\end{array}$} & \multicolumn{2}{|c|}{ Group $1 \mathrm{n}=28$} & \multicolumn{2}{|c|}{ Group $2 \mathrm{n}=27$} & \multicolumn{2}{|c|}{ Group $3 n=28$} & \multicolumn{2}{|c|}{ Group $4 \mathrm{n}=28$} \\
\hline & & $\mathrm{x} \pm \mathrm{Sx}$ & $\mathrm{VC}, \%$ & $\mathrm{x} \pm \mathrm{Sx}$ & $\mathrm{VC}, \%$ & $\mathrm{x} \pm \mathrm{Sx}$ & $\mathrm{VC}, \%$ & $\mathrm{x} \pm \mathrm{Sx}$ & $\begin{array}{c}\mathrm{VC}, \\
\%\end{array}$ \\
\hline \multirow{4}{*}{$\begin{array}{c}\text { Body } \\
\text { weight, } g\end{array}$} & 35 & $\begin{array}{c}2195,1 \\
\pm 40,58^{\mathrm{c}} \\
\end{array}$ & 9,96 & $\begin{array}{r}2181,8 \\
\pm 35,99^{\mathrm{c}} \\
\end{array}$ & 8,88 & $\begin{array}{c}2250,8 \\
\pm 34,15^{\mathrm{c}} \\
\end{array}$ & 8,17 & $\begin{array}{c}2845,3 \\
\pm 46,49^{\text {ccc }} \\
\end{array}$ & 8,8 \\
\hline & 42 & $\begin{array}{c}2845,3 \\
\pm 46,5\end{array}$ & 8,8 & $\begin{array}{l}2863,3 \\
\pm 42,43 \\
\end{array}$ & 7,98 & $\begin{array}{c}2894,7 \\
\pm 41,7 \\
\end{array}$ & 7,76 & $\begin{array}{r}2957,7 \\
\pm 37,36 \\
\end{array}$ & 6,8 \\
\hline & 49 & $\begin{array}{l}3367,0 \\
\pm 61,5^{\mathrm{b}}\end{array}$ & 9,84 & $\begin{array}{c}3450 \\
\pm 56,81 \\
\end{array}$ & 8,87 & $\begin{array}{r}3511,3 \\
\pm 38,75 \\
\end{array}$ & 5,94 & $\begin{array}{l}3563,7 \\
\pm 41,2^{b} \\
\end{array}$ & 6,23 \\
\hline & 56 & $\begin{array}{c}4220 \\
\pm 60,35\end{array}$ & 7,7 & $\begin{array}{l}4230,3 \\
\pm 65,55\end{array}$ & 8,34 & $\begin{array}{l}4246,7 \\
\pm 60,91 \\
\end{array}$ & 7,72 & $\begin{array}{c}\mathbf{4 2 8 7} \\
\pm \mathbf{5 4 , 7 7}\end{array}$ & 6,88 \\
\hline \multirow{4}{*}{$\begin{array}{c}\text { Average } \\
\text { weekly } \\
\text { gain, g }\end{array}$} & $29-35$ & $\begin{array}{r}775,9 \\
\pm 40,27 \\
\end{array}$ & 27,95 & $\begin{array}{c}697,9 \\
\pm 40,58 \\
\end{array}$ & 31,31 & $\begin{array}{c}710,273 \\
\pm 35,99 \\
\end{array}$ & 27,29 & $\begin{array}{c}629,1 \\
\pm 34,15 \\
\end{array}$ & 29,23 \\
\hline & $36-42$ & $\begin{array}{l}680,6 \\
\pm 46,5 \\
\end{array}$ & 36,79 & $\begin{array}{c}668,2 \\
\pm 42,43 \\
\end{array}$ & 34,19 & $\begin{array}{l}712,9 \\
\pm 41,7 \\
\end{array}$ & 31,5 & $\begin{array}{r}706,8 \\
\pm 37,4 \\
\end{array}$ & 28,47 \\
\hline & $43-49$ & $\begin{array}{l}521,7 \\
\pm 61,5\end{array}$ & 63,49 & $\begin{array}{c}586,7 \\
\pm 56,81 \\
\end{array}$ & 52,15 & $\begin{array}{l}\mathbf{6 1 6 , 7} \\
\pm 38,8 \\
\end{array}$ & 33,84 & $\begin{array}{l}606,0 \\
\pm 41,2 \\
\end{array}$ & 36,6 \\
\hline & $50-56$ & $\begin{array}{c}853 \\
\pm 60,35 \\
\end{array}$ & 38,1 & $\begin{array}{c}780,3 \\
\pm 65,55 \\
\end{array}$ & 45,23 & $\begin{array}{c}735,3 \\
\pm 60,91 \\
\end{array}$ & 44,6 & $\begin{array}{r}723,3 \\
\pm 54,8 \\
\end{array}$ & 40,8 \\
\hline \multirow{4}{*}{$\mathrm{FCR} \mathrm{kg/kg}$} & $0-35$ & $\underset{\substack{\text { aa } \\
1,52 \pm 0,03}}{ }$ & 10,9 & $1,44 \pm 0,03^{\mathrm{a}}$ & 10,39 & $1,45 \pm 0,02$ & 9,12 & $\begin{array}{c}1,44 \pm 0,0 \\
2^{\mathrm{a}}\end{array}$ & 7,91 \\
\hline & $0-42$ & $\begin{array}{c}1,72 \pm 0,03 \\
\mathrm{a}\end{array}$ & 9,22 & $1,64 \pm 0,02$ & 7,95 & $1,64 \pm 0,02^{a}$ & 7,87 & $\begin{array}{c}1,67 \pm 0,0 \\
2 \\
\end{array}$ & 6,97 \\
\hline & $0-49$ & $\underset{\mathrm{ac}}{1,96 \pm 0,04}$ & 9,69 & $1,86 \pm 0,03^{\mathrm{a}}$ & 8,79 & $1,83 \pm 0,02^{c}$ & 5,78 & $\begin{array}{c}1,86 \pm 0,0 \\
2^{\mathrm{a}}\end{array}$ & 6,26 \\
\hline & $0-56$ & $1,97 \pm 0,03$ & 7,89 & $1,94 \pm 0,03$ & 8,56 & $1,93 \pm 0,03$ & 7,75 & $\begin{array}{c}1,95 \pm 0,0 \\
2 \\
\end{array}$ & 6,9 \\
\hline
\end{tabular}

With 1, 2, 3 and 4 the corresponding groups are indicated: 1- control; 2- group with $0.2 \%$ garlic powder; 3- group with $0.4 \%$ garlic powder; 4 - group with $0.8 \%$ garlic powder in the feed.

Means within a row with the same superscripts are significantly different (aa- $p<0.05$; bb- $p<0.01 ; c c-p<0.001$ ).

The dynamics of weekly weight gain did not show a consistent tendency. In the period 29-35 days of age, control chickens showed the highest weight gain $(775.9 \pm 40.27 \mathrm{~g})$. At the same time, the feed intake by controls was also higher, which was anticipated. Over the entire 56-day experimental period, the highest weekly weight gain was recorded during the $4^{\text {th }}$ week (between $836.4 \pm 23.37 \mathrm{~g}$ and $930 \pm 36.49 \mathrm{~g}$ ). This period was also characterised with marked increase in feed intake, which has partly compensated the gap between body weight and technological reference weight of the hybrid. The substantial variation of the trait (VC, \% between $27.29 \%$ and $63.49 \%$ ), particularly after 42 days of age, should be emphasized.

Up to $35^{\text {th }}$ day of life, all four groups had better feed conversion ratios as compared to the technological norm $(\mathrm{FCR}=1.53)$. The difference in controls was especially obvious. Feed conversion ratio $(\mathrm{kg} / \mathrm{kg})$ maintained was steadily positively influenced by the garlic powder supplement until 49 days of age. The best feed conversion was exhibited by the group supplemented with $0.4 \%$ garlic powder, with statistically significant differences vs controls $(\mathrm{P}<0.001)$.

In agreement with our results, a positive effect of the dietary garlic powder supplement was also reported by Elagib et al. (16), Gbenda et al. (18), Fayed et al. (19) and Mansoub (20). On the other hand Choi et al. (22) have not observed any positive influence on the growth performance of experimental groups vs the control one, although the concentrations of the garlic powder supplement were higher.

Table 2 presents the results from the slaughter analysis carried out at 56 days of age. The highest carcass yield was found out in the group 
supplemented with $0.8 \%$ garlic powder and in control group: $74.3 \pm 1.59$ and $74.02 \pm 0.33 \%$, respectively. The lowest yield was obtained in the second group $(71.45 \pm 2.55 \%)$, in marked contrast both to other groups and hybrid's technological norm $(74.33 \%)$, which could be hardly explained. The relative share of edible offal did not tend to change by increasing dietary levels of garlic powder. Similar results were obtained by Fayed et al. (19). In our experiment, no correlation to the reduction of the relative weight of the spleen could be observed, as indicated by Elagib et al. (16). In contrast to the reduced deposition of abdominal fat after feed supplementation with 0.5 and $0.05 \%$ garlic powder reported by Gbenda et al. (18), we established the reverse tendency -increased abdominal fat in groups which received $0.4 \%$ and $0.8 \%$ garlic powder with their feed.

Table 2. Slaughter characteristics.

\begin{tabular}{|c|c|c|c|c|c|c|}
\hline \multirow{2}{*}{\multicolumn{2}{|c|}{ Group }} & 1 & 2 & 3 & 4 & Significance \\
\hline & & $\mathrm{x} \pm \mathrm{Sx}$ & $\mathrm{X} \pm \mathrm{Sx}$ & $\mathrm{x} \pm \mathrm{Sx}$ & $\mathrm{x} \pm \mathrm{Sx}$ & $\mathrm{x} \pm \mathrm{Sx}$ \\
\hline \multicolumn{2}{|c|}{ Carcass yield,\% } & $74,02 \pm 0,33$ & $71,45 \pm 2,55$ & $73,06 \pm 0,49$ & $74,3 \pm 1,59$ & NS \\
\hline \multirow{12}{*}{$\begin{array}{l}\text { Relative } \\
\text { weight, \% }\end{array}$} & Neck & $1,45 \pm 0,18$ & $1,35 \pm 0,08$ & $1,29 \pm 0,13$ & $1,18 \pm 0,09$ & NS \\
\hline & Gizzard & $1,24 \pm 0,13$ & $1,46 \pm 0,17$ & $1,36 \pm 0,04$ & $1,37 \pm 0,21$ & NS \\
\hline & Liver & $2,12 \pm 0,27$ & $1,89 \pm 0,3$ & $1,77 \pm 0,08$ & $1,78 \pm 0,2$ & NS \\
\hline & Spleen & $0,1 \pm 0,01$ & $0,08 \pm 0,01$ & $0,14 \pm 0,01$ & $0,12 \pm 0,01$ & $\begin{array}{l}1: 2^{* *} ; 1: 3^{* *} ; \\
2: 3 * * * ; \\
2: 4 * * *\end{array}$ \\
\hline & Heart & $0,44 \pm 0,05$ & $0,41 \pm 0,05$ & $0,38 \pm 0,03$ & $0,42 \pm 0,04$ & NS \\
\hline & $\begin{array}{l}\text { Abdominal } \\
\text { fat }\end{array}$ & $0,32 \pm 0,08$ & $0,26 \pm 0,03$ & $0,73 \pm 0,16$ & $0,73 \pm 0,11$ & $\begin{array}{c}1: 3^{* *} ; 1: 4^{* *} ; \\
2: 3^{* *} ; \\
2: 4^{* * *} ;\end{array}$ \\
\hline & Wing^^ & $3,7 \pm 0,17$ & $3,6 \pm 0,06$ & $3,9 \pm 0,06$ & $3,9 \pm 0,12$ & $\begin{array}{l}2: 3 * * * ; \\
2: 4 * * ;\end{array}$ \\
\hline & $\begin{array}{l}\text { Maryland } \\
\text { with Back } \\
\text { Bone } \\
\end{array}$ & $9,76 \pm 0,65$ & $9,38 \pm 0,54$ & $\mathbf{9 , 8 5} \pm \mathbf{0 , 1 7}$ & $9,65 \pm 0,21$ & NS \\
\hline & Drumstick & $5,06 \pm 0,43$ & $4,9 \pm 0,24$ & $5,2 \pm 0,06$ & $5,0 \pm 0,11$ & NS \\
\hline & $\begin{array}{l}\text { Breast Bone } \\
\text { In }\end{array}$ & $29,9 \pm 2,83$ & $27,2 \pm 1,15$ & $29,7 \pm 0,69$ & $29,43 \pm 0,3$ & NS \\
\hline & $\begin{array}{l}\text { Breast Fillet } \\
\text { Skinless }\end{array}$ & $10,14 \pm 0,61$ & $8,5 \pm 0,1$ & $10,32 \pm 0,16$ & $9,9 \pm 0,34$ & $\begin{array}{l}1: 2^{* * *} \\
2: 3 * * * ; \\
2: 4 * * * ;\end{array}$ \\
\hline & $\begin{array}{c}\text { Breast } \\
\text { tenderloin }\end{array}$ & $1,97 \pm 0,08$ & $2,02 \pm 0,19$ & $1,93 \pm 0,03$ & $1,87 \pm 0,06$ & NS \\
\hline
\end{tabular}

With 1, 2, 3 and 4 the corresponding groups are indicated: 1- control; 2- group with $0.2 \%$ garlic powder; 3- group with $0.4 \%$ garlic powder; 4 - group with $0.8 \%$ garlic powder in the feed

$\wedge$ With respect to the live body weight

$\wedge \wedge$ whole wing including drummette, wingette and the wing tip

${ }^{*} \mathrm{p}<0.05 ; * * \mathrm{p}<0.01 ; * * * \mathrm{p}<0.001 ;$ NS- Non Significant

The proportion of thighs (with a part of the back) from live body weight of the chickens varied from $28.56 \%$ (II group) to $30.1 \%$ (III group). A statistically significantly higher relative weight of wings was found out in groups III and IV compared to group II (at $\mathrm{P}<0.001$ and $\mathrm{P}<0.01$, respectively). The relative weight of breast with the bone was the highest in controls $(29.9 \pm 2.83 \%)$, and the lowest in the second group $(27.2 \pm 1.15 \%)$. The breast muscle percentage varied between $21.04 \%$ and $24.5 \%$.

The comparison of results with technological data of the broiler hybrid showed that except for the second experimental group, the others were in compliance with norms. With regard to slaughter traits, it could be affirmed that the garlic powder supplement did not influence the proportions of edible offal and the different cuts except for abdominal fat. Our results were 
comparable to those of Gbenda et al. (18) and Abdullah et al. (24) but disagree with reports for beneficial effect of dietary garlic powder supplement on slaughter traits demonstrated by Elagib et al. (16) Raeesi et al. (14), Fayed et al. (19) and on relative proportion of breast meat (23).
LUKANOV. H., et al.

Table 3 presents some basic physicochemical characteristics of studied muscles after 24-hour cold storage. The different muscles showed a similar variation in WHC values (68.6-85.9\%), with higher values for Musculus pectoralis superficialis. The results for the three studied muscles outlined a trend for negative influence of the garlic powder feed supplement on meat WHC.

Table 3. Changes of physicochemical characteristics in the sample from different muscle types (MpsMusculus pectoralis superficialis, Mpp- Musculus pectoralis profundus and Mftm- Musculus femorotibialis medialis) at 24th hour

\begin{tabular}{|c|c|c|c|c|c|c|c|c|}
\hline & \multicolumn{4}{|c|}{ Mps } & \multirow{2}{*}{\multicolumn{2}{|c|}{$\frac{\text { Mpp }}{\text { WHC,\% }}$}} & \multirow{2}{*}{\multicolumn{2}{|c|}{$\begin{array}{c}\text { Mftm } \\
\text { WHC, } \%\end{array}$}} \\
\hline Group & \multicolumn{2}{|c|}{ WHC, \% } & \multicolumn{2}{|c|}{ tenderness, ${ }^{\circ} \mathrm{P}$} & & & & \\
\hline & $\mathrm{x} \pm \mathrm{Sx}$ & $\mathrm{VC}, \%$ & $\mathrm{x} \pm \mathrm{Sx}$ & $\mathrm{VC}, \%$ & $\mathrm{x} \pm \mathrm{Sx}$ & $\mathrm{VC}, \%$ & $\mathrm{x} \pm \mathrm{Sx}$ & $\begin{array}{c}\mathrm{VC}, \\
\%\end{array}$ \\
\hline 1 & $80,25 \pm 1,86$ & 5,17 & $293,8 \pm 15,7$ & 19,28 & $78,25 \pm 1,03$ & 2,95 & $79,3 \pm 1,62$ & 4,57 \\
\hline 2 & $77,25 \pm 0,84$ & 2,42 & $279 \pm 12,8$ & 16,5 & $74,74 \pm 1,81$ & 5,43 & $79,03 \pm 0,91$ & 2,58 \\
\hline 3 & $77,6 \pm 1,44$ & 4,15 & $346 \pm 6,28$ & 6,55 & $75,54 \pm 1,94$ & 5,74 & $74,4 \pm 1,83$ & 5,5 \\
\hline 4 & $77,4 \pm 2,3$ & 6,65 & $335,3 \pm 9,36$ & 10,06 & $77,2 \pm 0,66$ & 1,91 & $78,4 \pm 2,01$ & 5,74 \\
\hline Significance & \multicolumn{2}{|l|}{ NS } & \multicolumn{2}{|c|}{$\begin{array}{c}1: 3 * * ; 1: 4 * ; \\
2: 3 * * * ; 2: 4 * * * ;\end{array}$} & \multicolumn{2}{|l|}{$\mathrm{NS}$} & \multicolumn{2}{|c|}{$1: 3^{*} ; 2: 3^{*}$} \\
\hline $\begin{array}{l}\text { Total } \\
\mathbf{x} \pm \mathbf{S x}\end{array}$ & \multicolumn{2}{|c|}{$78,12 \pm 0,78$} & \multicolumn{2}{|c|}{$313,5 \pm 56,4$} & \multicolumn{2}{|c|}{$76,44 \pm 0,7$} & \multicolumn{2}{|c|}{$\mathbf{7 7 , 8} \pm \mathbf{0 , 8 3}$} \\
\hline
\end{tabular}

With 1, 2, 3 and 4 the corresponding groups are indicated: 1- control; 2- group with $0.2 \%$ garlic powder; 3- group with $0.4 \%$ garlic powder; 4 - group with $0.8 \%$ garlic powder in the feed.

$* \mathrm{p}<0.05 ; * * \mathrm{p}<0.01 ; * * * \mathrm{p}<0.001 ;$ NS- Non Significant

Meat tenderness varied within a rather broad range from 173 to $400{ }^{\circ} \mathrm{P}$. The higher ${ }^{\circ} \mathrm{P}$ values determined in different points of Musculus pectoralis superficialis from broilers receiving 0.4 and $0.8 \%$ garlic powder deserve attention. These results are in agreement in those reported by Kim et al. (21) about improved chicken meat texture and flavour in boilers fed garlic powder. On the contrary, Choi et al. (22) and Abdullah et al. (24) did not demonstrate any effect on meat tenderness in broiler chickens supplemented with garlic.

Meat $\mathrm{pH}$ values were the highest immediately after slaughter. During the subsequent $24 \mathrm{~h}$, they decreased to 5.41-5.47 for breast muscles and 5.75 for Musculus femorotibialis medialis (Figure 3), which is anticipated at the background of the different morphological structure of analysed muscles. Throughout the period, meat $\mathrm{pH}$ decrease was more intensive during the first 4 post mortem hours $(\mathrm{P}<0.001)$, with higher differences in breast muscles.
Comparable time courses of muscle glycolysis have been also observed in Japanese quails (28). The interpretation of meat $\mathrm{pH}$ values with respect to feed garlic powder levels revealed that the tested factor had no significant impact (Figure 4). The between-group differences for the individual muscles were $<1 \%$, in support to results of Dzinic et al. (23).

The analysis of colour characteristics of studied muscles in the CIELAB system showed lightness values ( $\mathrm{L}^{*}$ ) between c 49 and 66.1. The redness (a*) varied from 2.5 and 11.4 in breast muscles and within 8.8-15.9 in Musculus femorotibialis medialis. The values of $\mathrm{b}^{*}$ for three studied muscles were between 5.6 and 17.9. Therefore, the total pigment saturation was the highest in Musculus femorotibialis medialis with average values $a^{*}=11.7 \pm 0.26 ; b^{*}=13.3 \pm 0.36$. As the change of colour with post mortem time was concerned, the values of colour coordinates went higher, particularly in breast muscles (Table 4). For Musculus femorotibialis medialis, a similar 
relationship was observed only with regard to a* coordinate. From the moment of death until the $24^{\text {th }}$ post mortem hour, L* of breast muscles increased slightly, especially in Musculus pectoralis superficialis $(\mathrm{P}<0.001)$. In contrast, the lightness of Musculus femorotibialis medialis
LUKANOV. H., et al. has slightly decreased at that time $(\mathrm{P}<0.001)$. The pigmentation of the three muscles in the redgreen spectrum was higher with statistically significant differences for Musculus pectoralis superficialis $\quad(\mathrm{P}<0.001) \quad$ and Musculus femorotibialis medialis $(\mathrm{P}<0.01)$.

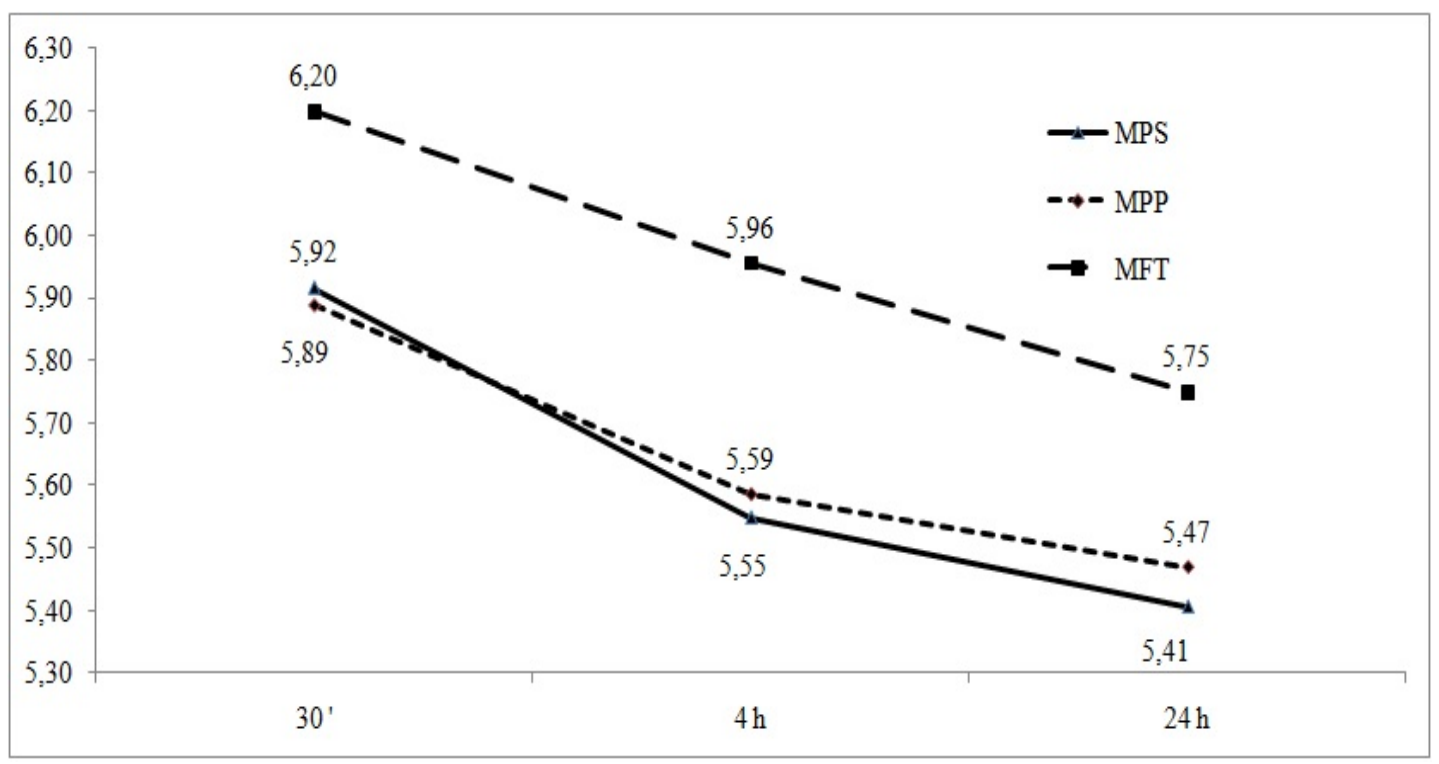

Figure 3. Time course of post mortem meat $\mathrm{pH}$ reduction

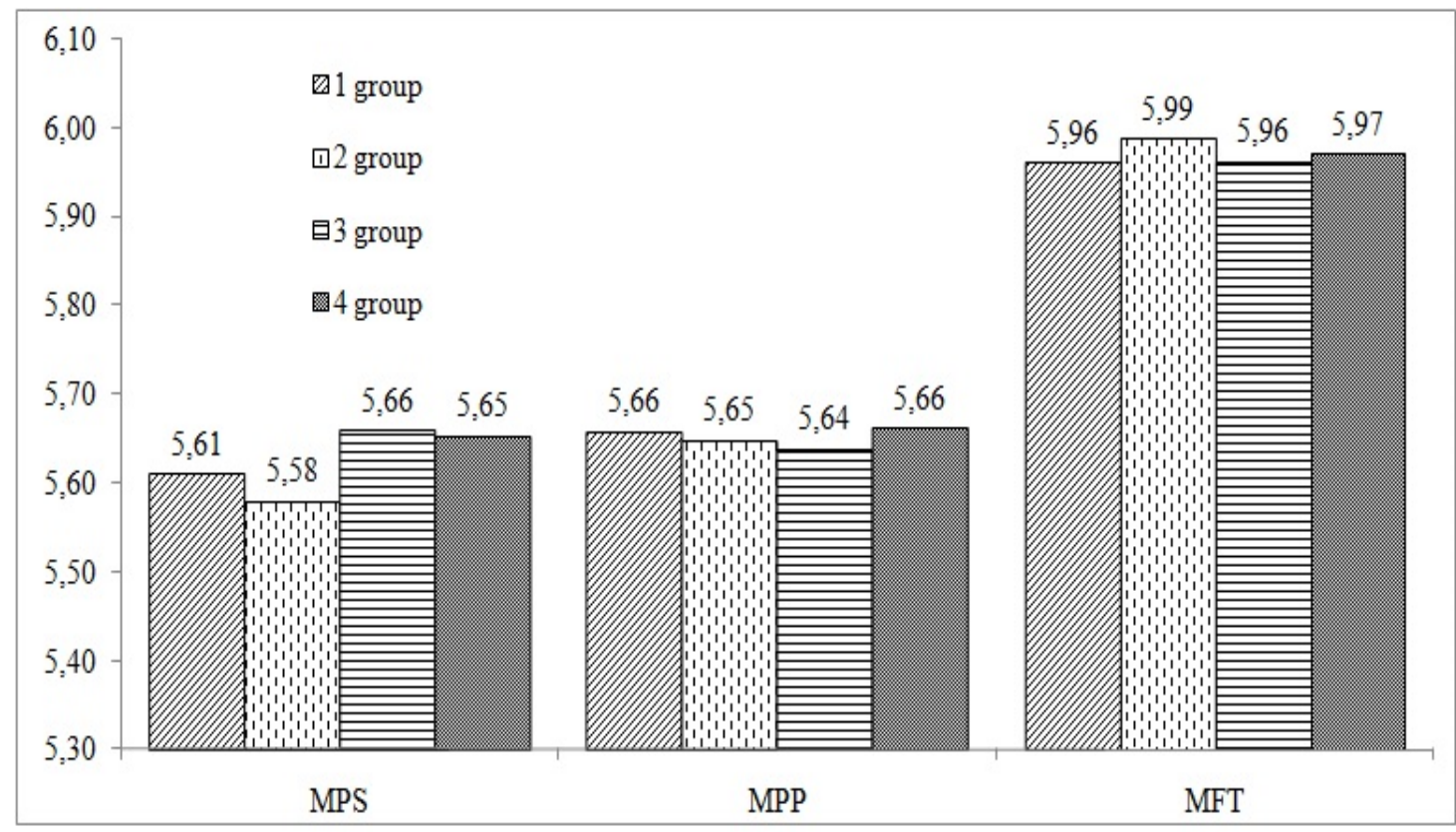

Figure 4. Meat $\mathrm{pH}$ depending on dietary garlic powder levels

The analysis of effects of feed supplementation with garlic power on colour characteristics of meat did not allow us to draw a consistent conclusion due to the low number of samples. The values of $\mathrm{L}^{*}, \mathrm{a}^{*}$ and $\mathrm{b}^{*}$ coordinates in the different groups were similar and did not outline any relevant tendency of relationship with the tested factor.

The colour characteristics of Musculus pectoralis superficialis with respect to the site of analysis 
allowed assuming the results obtained from the medial surface of the muscle as more accurate and reliable (Figure 5). The presence of Fascia pectoralis from the lateral side led to a stronger reflexion and scattering of light and consequently, compromised the precision of the
LUKANOV. H., et al. analysis as obtained $\mathrm{L}^{*}$ values were by about $7 \%$ higher $(\mathrm{P}<0.001)$, and $\mathrm{a}^{*}$ and $\mathrm{b}^{*}$ values - by about $14 \%$ lower (at $\mathrm{P}<0.001$ and $\mathrm{P}<0.01$, respectively) than those measured on the medial surface.

Table 4. Colour coordinates of broiler chicken meat.

\begin{tabular}{|c|c|c|c|c|c|c|c|c|c|}
\hline & \multicolumn{3}{|c|}{ Mps } & \multicolumn{3}{|c|}{ Mpp } & \multicolumn{3}{|c|}{ Mftm } \\
\hline & $\mathrm{L}$ & a & $\mathrm{b}$ & $\mathrm{L}$ & $a$ & $\mathrm{~b}$ & $\mathrm{~L}$ & a & b \\
\hline \multicolumn{10}{|c|}{ Depending on the post mortem time } \\
\hline $30 "$ & $\begin{array}{l}50,91 \\
\pm 0,73\end{array}$ & $\begin{array}{c}3,50 \\
\pm 0,18\end{array}$ & $\begin{array}{c}5,76 \\
\pm 0,34\end{array}$ & $\begin{array}{l}51,75 \\
\pm 0,67\end{array}$ & $\begin{array}{c}6,32 \\
\pm 0,22\end{array}$ & $\begin{array}{c}9.96 \\
\pm 0,41\end{array}$ & $\begin{array}{l}59,64 \\
\pm 0,41\end{array}$ & $\begin{array}{r}10,56 \\
\pm 0,36\end{array}$ & $\begin{array}{l}13,10 \\
\pm 0,38\end{array}$ \\
\hline $4 \mathrm{~h}$ & $\begin{array}{l}54,28 \\
\pm 0,62\end{array}$ & $\begin{array}{c}4,11 \\
\pm 0,16\end{array}$ & $\begin{array}{c}7,24 \\
\pm 0,35\end{array}$ & $\begin{array}{l}53,73 \\
\pm 0,70\end{array}$ & $\begin{array}{c}6,39 \\
\pm 0,26\end{array}$ & $\begin{array}{l}10.70 \\
\pm 0,39\end{array}$ & $\begin{array}{l}58,60 \\
\pm 0,42\end{array}$ & $\begin{array}{l}10,74 \\
\pm 0,35\end{array}$ & $\begin{array}{l}12,70 \\
\pm 0,33\end{array}$ \\
\hline $24 \mathrm{~h}$ & $\begin{array}{l}58,86 \\
\pm 0,75 \\
\end{array}$ & $\begin{array}{c}5,62 \\
\pm 0,22 \\
\end{array}$ & $\begin{array}{l}10,26 \\
\pm 0,45 \\
\end{array}$ & $\begin{array}{l}53,03 \\
\pm 0,53 \\
\end{array}$ & $\begin{array}{c}6,76 \\
\pm 0,20 \\
\end{array}$ & $\begin{array}{l}11,07 \\
\pm 0,29\end{array}$ & $\begin{array}{l}57,58 \\
\pm 0,39\end{array}$ & $\begin{array}{r}11,70 \\
\pm 0,26\end{array}$ & $\begin{array}{l}13,31 \\
\pm 0,36\end{array}$ \\
\hline Significance & $\begin{array}{l}1-2 * * * ; \\
2-3 * * * ; \\
1-3 * * * ;\end{array}$ & $\begin{array}{l}1-2 * ; \\
2-3 * * ; \\
1-3 * * *\end{array}$ & $\begin{array}{l}1-2 * * * ; \\
2-3 * * * ; \\
1-3 * * *\end{array}$ & $1-2 * *$ & NS & $1-3 *$ & $1-3 * * *$ & $\begin{array}{c}2-3^{*} \\
1-3^{* *}\end{array}$ & NS \\
\hline \multicolumn{10}{|c|}{ Depending on the garlic powder addition } \\
\hline 1 & $\begin{array}{l}54,12 \\
\pm 0,93\end{array}$ & $\begin{array}{c}3,76 \\
\pm 0,26\end{array}$ & $\begin{array}{c}7,66 \\
\pm 0,62\end{array}$ & $\begin{array}{l}51,32 \\
\pm 0,54\end{array}$ & $\begin{array}{c}6,37 \\
\pm 0,29\end{array}$ & $\begin{array}{l}10,61 \\
\pm 0,65\end{array}$ & $\begin{array}{l}58,69 \\
\pm 0,51\end{array}$ & $\begin{array}{l}11,85 \\
\pm 0,52\end{array}$ & $\begin{array}{c}13,14 \\
\pm 0,58\end{array}$ \\
\hline 2 & $\begin{array}{l}56,07 \\
\pm 0,82 \\
\end{array}$ & $\begin{array}{c}4,86 \\
\pm 0,28 \\
\end{array}$ & $\begin{array}{c}9,48 \\
\pm 0,50 \\
\end{array}$ & $\begin{array}{l}54,25 \\
\pm 1,13 \\
\end{array}$ & $\begin{array}{c}6,42 \\
\pm 0,28 \\
\end{array}$ & $\begin{array}{l}10,67 \\
\pm 0,46 \\
\end{array}$ & $\begin{array}{l}57,73 \\
\pm 0,37 \\
\end{array}$ & $\begin{array}{l}10,11 \\
\pm 0,21 \\
\end{array}$ & $\begin{array}{r}12,78 \\
\pm 0,19 \\
\end{array}$ \\
\hline 3 & $\begin{array}{r}53,25 \\
\pm 1,19 \\
\end{array}$ & $\begin{array}{c}4,42 \\
\pm 0,27\end{array}$ & $\begin{array}{c}7,38 \\
\pm 0,59\end{array}$ & $\begin{array}{l}51,85 \\
\pm 0,51\end{array}$ & $\begin{array}{c}6,20 \\
\pm 0,25\end{array}$ & $\begin{array}{l}10.72 \\
\pm 0,29\end{array}$ & $\begin{array}{l}59,11 \\
\pm 0,42\end{array}$ & $\begin{array}{l}10,11 \\
\pm 0,22\end{array}$ & $\begin{array}{l}13,55 \\
\pm 0,40\end{array}$ \\
\hline 4 & $\begin{array}{l}55,17 \\
\pm 1,21\end{array}$ & $\begin{array}{c}4,60 \\
\pm 0,28\end{array}$ & $\begin{array}{c}6,50 \\
\pm 0,44\end{array}$ & $\begin{array}{l}53,93 \\
\pm 0,50\end{array}$ & $\begin{array}{c}6,96 \\
\pm 0,21\end{array}$ & $\begin{array}{l}10,30 \\
\pm 0,24\end{array}$ & $\begin{array}{l}58,90 \\
\pm 0,63\end{array}$ & $\begin{array}{l}11,93 \\
\pm 0,35\end{array}$ & $\begin{array}{l}12,67 \\
\pm 0,40\end{array}$ \\
\hline Significance & & $\begin{array}{c}1-2 * * \\
1-4 *\end{array}$ & $\begin{array}{c}1-2 * \\
2-3 * * ; \\
2-4 * * *\end{array}$ & $\begin{array}{c}1-2 * ; \\
1-3 * * * ; \\
3-4 * *\end{array}$ & NS & NS & $2-3 *$ & $\begin{array}{l}1-2 * * \\
1-3 * * \\
2-4 * * \\
3-4 * *\end{array}$ & NS \\
\hline
\end{tabular}

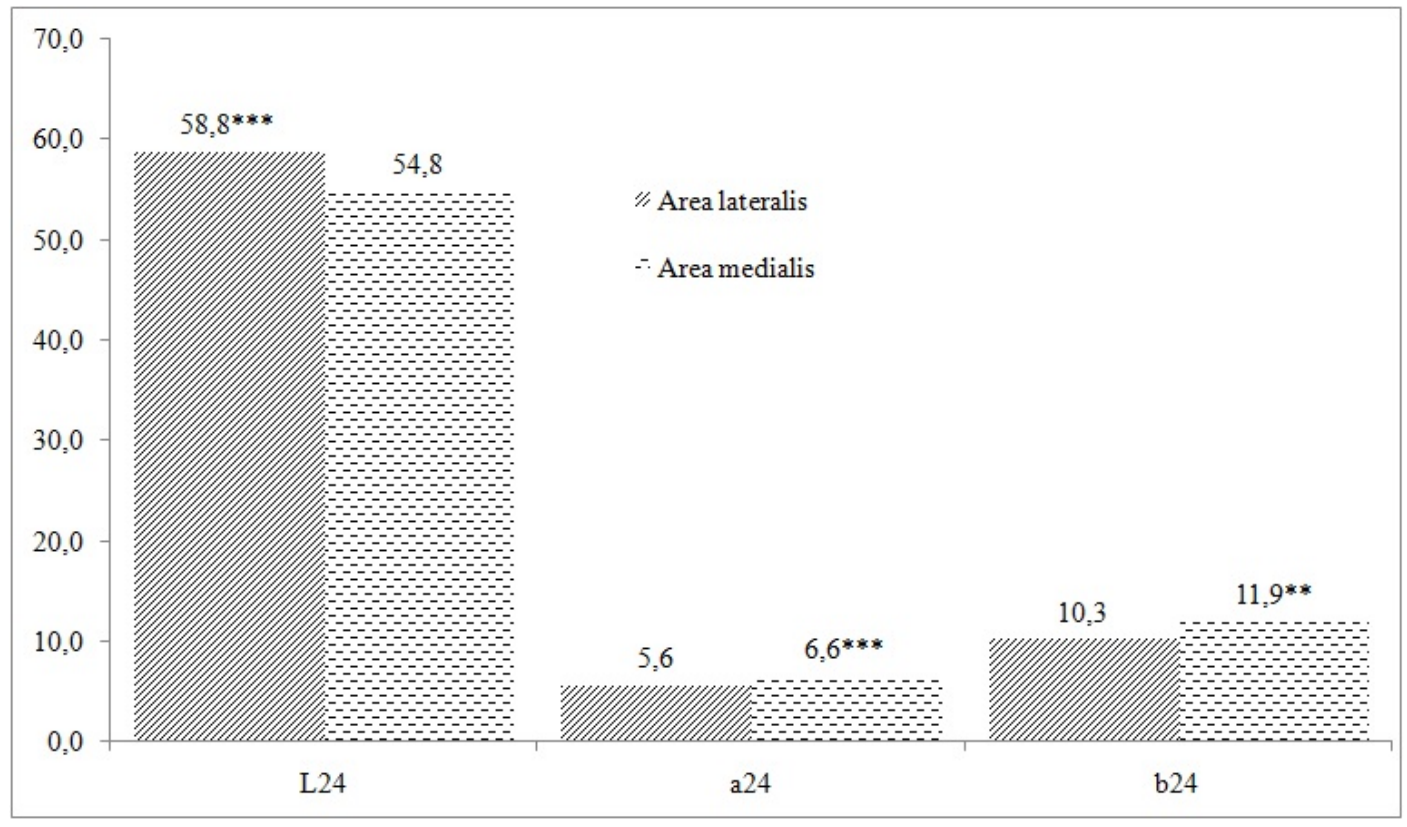

Figure 5. Colour coordinates of Musculus pectoralis superficialis with regard to the analysis site. 


\section{CONCLUSION}

- After 25 days of age, the live weight of broiler chickens was influenced by the dietary garlic powder content;

- There was a steady tendency towards increased live body weight proportionally to dietary garlic powder level;

- Feed conversion ratio $(\mathrm{kg} / \mathrm{kg})$ maintained a steady positive trend in relation to feed supplementation with garlic powder with increasing doses until the $7^{\text {th }}$ week of age;

- Garlic powder supplementation of feed did not influence the share of edible offal and meat cuts, except for abdominal fat percentage;

- Garlic powder supplementation did not have an adverse effect on chicken meat quality traits. There is statistically significant increase in meat tenderness in groups supplemented with 0.4 and $0.8 \%$ garlic powder.

\section{RECOMMENDATIONS}

On the basis of the most consistent economic parameter of broiler farming - feed conversion ratio - the addition of $0.4 \%$ garlic powder to the feed of fattening broiler chickens up to 49 days of age is recommended.

For more accurate quantitative analysis of meat colour, the measurements of Musculus pectoralis superficialis should be preferably done on the medial surface of the muscle.

\section{REFERENCES}

1. Neu, H., The Crisis in Antibiotic Resistance. Science, 257 (5073): 1064-1073, 1992.

2. Gupta, A.R., The benefits of probiotics in poultry production: an overview. International Journal of Livestock Research, 3(1): 18-22, 2013.

3. Gabriel. I., Lessire, M., Mallet, S. and Guillot, J.F., Microflora of the digestive tract: critical factors and consequences for poultry. World's Poultry Science Journal, 62 (3): 499511, 2006.

4. Gibson, G.R. and Roberfroid, M.B., Dietary modulation of the human colonic microbiota: introducing the concept of prebiotics. The Journal of Nutrition, 125 (6): 1401-1412, 1995.

5. Hajati, H. and Rezaei, M., The Application of Prebiotics in Poultry Production. International Journal of Poultry Science, 9 (3): 298-304, 2010.

6. Niness, K.R., Nutritional and Health Benefits of Inulin and Oligofructose Inulin and Oligofructose: What Are They? American
LUKANOV. H., et al.

Society for Nutritional Sciences: 1402S1406S, 1999.

7. Mussato, S.I. and Mancilha, I.M., Nondigestible oligosaccharides: A review. Carbohydrate Polymers, 68 (3): 587-597, 2007.

8. Yildiz, S., The metabolism of fructooligosaccharides and fructo-oligosacchariderelated compounds in plants. Food Reviews International, 27 (1): 16-50, 2009.

9. Qureshi, A.A., Din, Z.Z., Abuirmeileh, N., Burger, W.C., Ahmad, Y. and Elson, C.E., Suppression of avian hepatic lipid metabolism by solvent extracts of garlic: impact on serum lipids. The Journal of Nutrition, 113: 1746-1755, 1983.

10.Konjufca, V.H., Pesti, G.M. and Bakalli, R.I., Modulation of cholesterol levels in broiler meat by dietary garlic and copper. Poultry Science, 76:1264-1271, 1997.

11.Campbell, J.M., Bauer, L.L., Fahey, G.C., Hogarth, A.J.C.L., Wolf, B.W. and Hunter, D.E., Selected fructooligosaccharides ( I kestose, nystose, and IF fructofuranosylnystose) composition of foods and feeds. Journal of Agricultural and Food Science, 45 (8): 3076-3082, 1997.

12.Amagase, H., Petesch, B.L., Matsuura, H., Kasuga, S. and Itakura, Y., Intake of garlic and its bioactive components. The Journal of Nutrition, 131 (3s): 955S-962S, 2001.

13.USDA, National Nutrient Database for Standard ReferenceRelease 27. Basic Report 02020, Spices, garlic powder. Report Date: September 29, 2014 22:01 EDT, 2014.

14.Raeesi, M., Hoeini-Aliabad, S.A., Roofchaee, A., Zare Shahneh, A. and Pirali, S., Effect of periodically use of garlic (Allium sativum) power on performance and carcass characteristics in broiler chickens. World Academy of Science, Engineering and Technology, 68: 1213- 1219, 2010.

15.Issa, K.J. and Omar, J.M.A., Effect of garlic powder on performance and lipid profile of broilers. Open Journal of Animal Sciences, 2 (2): 62-68, 2012.

16.Elagib, H.A.A., El-Amin, W.I.A., Elamin, K.M. and Malik, H.E.E., Effect of Dietary Garlic (Allium sativum) Supplementation as Feed Additive on Broiler Performance and Blood Profile. Journal of Animal Science Advances, 3 (2): 58-64, 2013.

17.Gerzilov, V., Nikolov, A., Petrov, P., Bozakova, N., Penchev, G. and Bochukov, A., Effect of a Dietary Herbal Mixture 
Supplement on the Growth Performance, Egg Production and Health Status in Chickens. 8th International Conference of Journal of Central European Agriculture "The role of animal production in rural development in the region of Central and Eastern Europe", 20-22 November 2013, . Journal of Central European Agriculture, 2014. (in press)

18.Gbenda, O.E., Adebisi, O.E., Fajemisin, A.N. and Adetunji, A.V., Response of broiler chickens in terms of performance and meat quality to garlic (Allium sativum) supplementation. African Journal of Agricultural Research, 4 (5): 511-517, 2009.

19.Fayed, R.H., Razek, A.H.A. and Jehan, M.O., Effect of dietary garlic supplementation on performance, carcass traits, and meat quality in broiler chickens. In Animal hygiene and sustainable livestock production. Proceedings of the XVth International Congress of the International Society for Animal Hygiene, Vienna, Austria, 3-7 July 2011, Volume 1, 2011, pp.: 471-474, 2011.

20.Mansoub, N.H., Comparative Effects of Using Garlic as Probiotic on Performance and Serum Composition of Broiler Chickens. Annals of Biological Research, 2 (3): 486490, 2011.

21.Kim, Y.J., Jin, S.K. and Yang, H.S., Effect of dietary garlic bulb and husk on the physicochemical properties of chicken meat. Poultry Science, 88 (2): 398-405, 2008.

22.Choi, I.H., Park, W.Y. and Kim, Y.J., Effects of dietary garlic powder and $\alpha$-tocopherol supplementation on performance, serum cholesterol levels, and meat quality of chicken. Poultry Science, 89: 1724-1731, 2010.

23.Dzinic, N., Okanovic, D., Jokanovic, M., Tomovic, V. and Dragan, P., The influence of garlic powder in broiler feed on carcass and breast meat quality. Quality of Life, 4 (3-4): 55-61, 2013.

24.Abdullah, A.Y., Mahmoud, K.Z., Nusairat, B.M. and Qudsieh, R.I., Small intestinal histology, production parameters, and meat quality as influenced by dietary supplementation of garlic (Allium sativum) in broiler chicks. Italian Journal of Animal Science, 9 (4): 414-419, 2010.

25.Aviagen, Ross 308, Ross 308 Management Handbook 2014. pp 132, 2014b.

26.CIE, Colorimetry. $2^{\text {nd }}$ edition. CIE Publication. No.15.2. Commission Internationale de I'Eclairage. Vienna, 1986.

27.Zahariev, Z., Pinkas, A., Methods about leading of experiments, slaughtering analysis and quality evaluation of the meat. NAPS, Sofia, 1979.

28. Ribarski, S., Genchev, A.,and S. Atanasova, Effect of cold storage terms on physicochemical properties of Japanese quail (Coturnix Coturnix japonica) meat. Agricultural Science and Technology, 5 (1):126-133, 2013. 